\title{
EVALUATION OF THE POLICY OF THE ELECTRONIC MANAGEMENT OF STATE PROPERTY IN UNIVERSITY OF SEBELAS MARET, SURAKARTA
}

\author{
Harisudin, Sudarmo, Rino Ardhian Nugroho \\ Faculty of Social Science and Political Science, University of \\ Sebelas Maret \\ Email : haris_karlo@yahoo.com
}

\begin{abstract}
This article analyzes the evaluation of the policy of management of State Goods Electronically in Sebelas Maret University of Surakarta. The scope of the Management of the State Property includes : Planning, procurement up to asset management obtained from the procurement (State Property). This is in line with government efforts to improve public services with e-government development electronic base that is used in the case of planning that is making RAB (Budget Plan) in the form of HPS (Own Price Estimated), TOR (Term of Reference) or determination of IKU (Unit Performance Indicator), IKA (Budget Performance Indicator) or MAK (activity budget item). In the process of procurement using e-procurement system also in the management of asset/BMN procurement result using the Application System of SIMAK BMN. Evaluation of the Policy done by looking at the 4 elements as follows : 1 1) To measure the effects Based on the research methodology used; 2) Effects Emphasize on an outcomes of Efficiency, honesty, morals attached to rules or standards; 3) Comparation between the effects and goals emphasizes on the use of clear criteria In assessing how a policy has been properly implemented, 4) Giving contribution to make future decision-making and future policy improvements as the social purpose of the evaluation.
\end{abstract}

Key words : Evaluation of Policy, management, state property,e-government 159 Yustisia Vol. 6 No. 1 January - April 2017 Evaluation of The Policy The Electronic... Attribution Licensee (https://creativecommons.org/licenses/by/4.0), which permits unrestricted use, distribution, and reproduction in any medium, provided the original work is properly cited. 


\section{A. INTRODUCTION}

Free market competition nowadays requires people to compete with other communities, both in science and skills. Many societies can not survive in this condition and ultimately fall behind. Not just the societies, but also the government of a country must also be able to survive the increasingly tight competition between countries and a country must also be able to take a policy that is able to prosper the societies where at certain times the policy has been taken to be evaluated. This is important to do in order to obtain information about the extent to which the policy achievement has been taken and to show the difference in policy achievement between before and after the implementation of a policy.

Law Number 25 of 1999 on the Financial Equilibrium between the Central Government and Regional Government and the Law Number 23 of 2014 on The Regional Autonomy and provides fresh air to the regions because the regions have the right and authority to regulate and manage their own households and to manage and utilize the potential of its region maximally in an effort to improve the progress and welfare of society (social welfare) that can be pursued by the fulfillment of facilities and infrastructure both physical and non-physical that can be implemented by procurement and management of assets / procurement goods.

Law Number 1 of 2004 On State Treasury pursuant to article 48 paragraph (2) and explanation of Article 49 paragraph (6) It is proposed that the scope of the State Property management arrangements in the Government Regulation shall include the sale of goods through the tender and its exceptions, the Requirement Planning, the Procurement, the Procedures of Use, the Utilization, the Maintenance, the Administration, the Assessment, the Abolition and the Transfer of and subsequently in the rules of execution the Government shall issue Government Regulation Number 6 of 2006 on the Management of State property / Region.

Between the management and accountability of state property (BMN) with the management and accountability of state finances has a very clear 
relationship. Management and accountability for financial management where BMN (State property) is included Is a form of financial statements of central government. In order to produce qualified financial report, the financial report should meet adequate criteria that are relevant, reliable, assessable or compared, and understandable. These four criteria are very important for the creation of good financial report quality as evidence of accountability of government budget usage.

Good Governance Requires equality and harmony between state institutions, markets (business community) and society (Three pillars of civil society).

The Government of the Republic of Indonesia to realize clean governance and implement good governance and in its efforts to improve public services is the development of e-government. The development of e-government is an effort to develop electronic government-based administration in order to improve the quality of public services effectively and efficiently.

The development of e-government in terms of state property management is implemented in an integrated manner from the development of electronic application systems in the areas of planning, procurement, asset management and reporting of ministerial level up to the central level.

In the field of Planning at the level of the Ministry of Research, Technology and Higher Education developed the application of System Planning and Evaluation of Integrated Performance as a media for input planning data up to the reporting activities that can be monitored online from the University level and to the national level ministerial level even to the President.

In the case of procurement, the Government has issued Presidential Decree Number 80 of 2003 on The Guidelines on the implementation of government procurement and in the development of e-government, one of which is the implementation of e-procurement regulated in Presidential Regulation Number 54 of 2010. The stipulation of Presidential Decree Number 80 of 2003 on the Guidelines for the Procurement of Properties / Services at Government Agencies is intended to obtain Properties or services at a price that can be accounted for in accordance with the amount and quality as well as in time and to 
avoid deviation of budget usage, especially in government agencies. In addition, as stated in article 2, paragraph 1 of Presidential Decree Number 80 of 2003 that the purpose of the enactment of this Presidential Decree is that the implementation of procurement of properties / services partly or wholly financed by APBN / $A P B D$ can be done efficiently, effectively, openly, competitively, Transparent, fair / non-discriminatory, and accountable so that the results can be accounted for in terms of physical, financial and benefits for government tasks and public service.

For the implementation of expenditure through the procurement process of properties and services it is necessary to:

1. Legal framework is the existence of legislation and more adequate procurement system.

2. Human resources namely the existence of Human Resources (HR) is sufficient in the capacity and professionalism, and

3. Institutional namely the institutional setting for monitoring, policy development and enforcement.

While in the case of asset management / state property used a system that is Management Information System and Accounting of state property (SIMAK BMN) which implemented pursuant to Regulation of Minister of Finance of Republic of Indonesia number 171 / PMK.05 of 2007 on The Accounting System and Financial Report of Central Government. SIMAK $\mathrm{BMN}$ is expected to produce information as a basis for preparing the balance of state ministries / institutions and other information required by other stakeholders concerned.

In line with the policy set by the government, in the management of State property in Sebelas Maret University of Surakarta The use of electronic system policy is used in the following phases: 1) Planning is by Application of Integrated Performance Planning and Evaluation System (SIREN), 2) Procurement is by e-Procurement using Electronic Procurement System (SPSE) organized by Electronic Procurement Service (LPSE) UNS, 3) 
Management of procured assets / goods by using SIMAK BMN Application (Management Information System and State Property Accounting).

With the stipulation of the use of electronic application policy in the management of state property in the Sebelas Maret University of by the Rector, all faculties and work units within the UNS must be subject to and follow the policy that is expected to overcome the problems that arise related to the management of State Property in the Sebelas Maret University of Surakarta.

In the case of planning there are several problems that arise, as follows:

1. Manually executed planning is known only to the faculty / work unit so that it is difficult to be coordinated and monitored by the university level moreover by a higher level.

2. The reporting system of activities that have been contained in the planning document whether the quarterly report, semester report or annual report requires a long time and inefficient because it must send a report in hardcopy form that is very thick.

3. The period of preparation of the Budget Business Plan (RBA) was implemented one year earlier so there are some activities that are sudden and urgent to be implemented in the current year have not been accommodated in the RBA and require budget revision so that it can lead to delays in the implementation of activities.

\section{B. PROBLEM STATEMENT}

Related to the procurement of goods / services within the University of Sebelas Maret that there are several problems that arise in the procurement process, including:

1. In the conventional procurement process there is a series of face-to-face between the committee and its partners (registration, aanwijzing, acceptance and opening of bidding documents, qualification verification) to enable the practice of $\mathrm{KKN}$ between the procurement committee and the supplier of properties / services. 
2. The conventional auction process is less effective and efficient in terms of time and cost and opportunities for partners to get a very heavy and limited job.

3. From the administrative and technical aspect of the conventional procurement process is quite difficult because the partners are burdened with procurement documents in the form of hardcopy documents are quite thick, the partners must also be present physically at every stage of the auction process / procurement, the confidentiality of the procurement not guaranteed and competition between partners Provider of properties / services is relatively closed.

4. Delays in the preparation process of HPS (Owner's Estimate Price) by the PPK (Committing Officer) because the user is late in submitting the goods / services request to the ULP so that the goods and capital expenditure process is too late and resulted in accumulation at the end of Fiscal Year.

5. Procurement / auction that is forced to fail or problematic because the provider / vendor in the implementation of the work is exposed to some problems including not timely in the completion of work in accordance with the provisions of the period of implementation of work contained in the SPK (Letter of Contract Agreement).

6. There is a fraud committed by the vendor in the auction process, such as the occurrence of CCO (Contract Change Order) is the Implementation of contracts procurement of properties / services in this case physical work sometimes often experience the job added / less can change the technical specifications of work in accordance with the needs So that in the procurement process is often experienced problems to the user and cause procurement documents not in accordance with work specifications implemented or properties that have discontinued not accompanied by changes (addendum) in the contract document resulting in the process of asset management / BMN becomes problematic. 
Other problems also arise after the procurement process is on asset management $(\mathrm{BMN})$ procurement results, including:

1. Asset management manually rely solely on manually recording assets in the inventory book of goods so that it can not provide accurate and valid data about the assets owned by the University either in terms of quantity, condition, existence or data about other assets needed.

2. The management of the assets manually causes less administrative ordering in terms of use, utilization, security and maintenance, valuation, deletion, alienation, coaching, supervision and asset control.

3. Procurement of goods / services that accumulate at the end of the fiscal year so as to cause the process of $\mathrm{BMN}$ management through the application of SIMAK BMN (Management Information System and State Property Accounting) experiencing constraints due to the delay of receipt of Fund Disbursement Order (SP2D) as the basis for inputting data in the application SIMAK BMN.

4. Procurement of goods is not appropriate (Specification, quality, and quantity) with procurement documents and no supporting information about the occurrence of such nonconformities (either in the form of contract addendum, discontinue certificate from the factory / distributor or other support).

Based on the above problems, then in the management of State property electronically starting from the stage of Planning, procurement through eprocurement to asset management / state property results of procurement must be implemented in accordance with provisions of policies and regulations that have been set, so that in the preparation of Balance Sheet can run with Both at the time of examination by both internal auditor UNS that is by the Internal Control System (SPI) and external auditors such as Inspectorate General (Irjen), Finance and Development Supervisory Board (BPKP), Supreme Audit Board (BPK) and other auditors can lead to WTP (Unqualified) 


\section{RESEARCH METHODS}

The research was conducted at the Procurement Service Unit (ULP) of Sebelas Maret University of Surakarta as a Work Unit conducting the eprocurement process through SPSE and Sebelas Maret University of Surakarta as well as the Administrative Unit of Power of Goods User (UPKPB) which handles and processes the State property management. The research method is using a descriptive qualitative research methods so that the data collected in the form of words or sentences trying to dig, find the facts and dive problems encountered related to the evaluation of the State property management policy electronically in the Sebelas Maret University of Surakarta so it can be known About the extent to which the achievement of policy implementation and what factors affect the implementation of electronic state property management policy. The technique of determining informants using purposive sampling is the sampling is adjusted to the purpose of research (Hadari Nawawi, 1985: 157). Primary data sources obtained by the respondents who have been determined in the sample research, ie officials and staff directly related to the implementation of planning, e-procurement and Asset Management / BMN in the Sebelas Maret University of Surakarta Environment. In addition, primary data also comes from direct observation in the field. Secondary data sources are obtained from Budget Breakdown Plan (RBA) documents, e-procurement implementation reports, procurement documents, SPSE Application data print outs, State property balance report, inventory numbering, Room Listing List (DBR), state property or Items already in use in state property operations. Data collection techniques with observation, interview and documentation. Data analysis techniques using interactive data analysis Miles and Huberman while the technique of examining the validity of data using triangulation techniques. 


\section{RESEARH RESULT AND DISCUSSION}

\section{Evaluation of Policy}

A public policy can not be taken away without evaluation. Policy evaluation is conducted to assess the extent to which the effectiveness of public policy to be accountable to the public in order to achieve the goals set. Evaluation is needed to see the gap between hope and reality. If policy is seen as a sequential activity, then policy evaluation is the final stage in the policy process (Winarno, 2008: 225).

There are three kinds of public policy evaluations, namely: (1) administrative evaluation, ie evaluation conducted within the scope of government or within agencies. The highlight of this evaluation is matters relating to public policy procedures and financial aspects; (2) judicial evaluation; is an evaluation relating to the objects of the law. Whether there is a violation of law or not from the public policy being evaluated; (3) a political evaluation, an evaluation concerning the political considerations of a policy (Putra, 2003: 100-101).

Policy evaluation is seen as a functional activity. That is, policy evaluation is not only done in the final stages but the entire policy process (Anderson: 1975). According to W. Dunn, the term evaluation has a related meaning, each pointing to the application of multiple value scales to the policy and program outcomes. Evaluation includes the conclusion + clarification + criticism + adjustment and re-formulation of the problem.

Figure 1 Evaluation of Policy

Scope

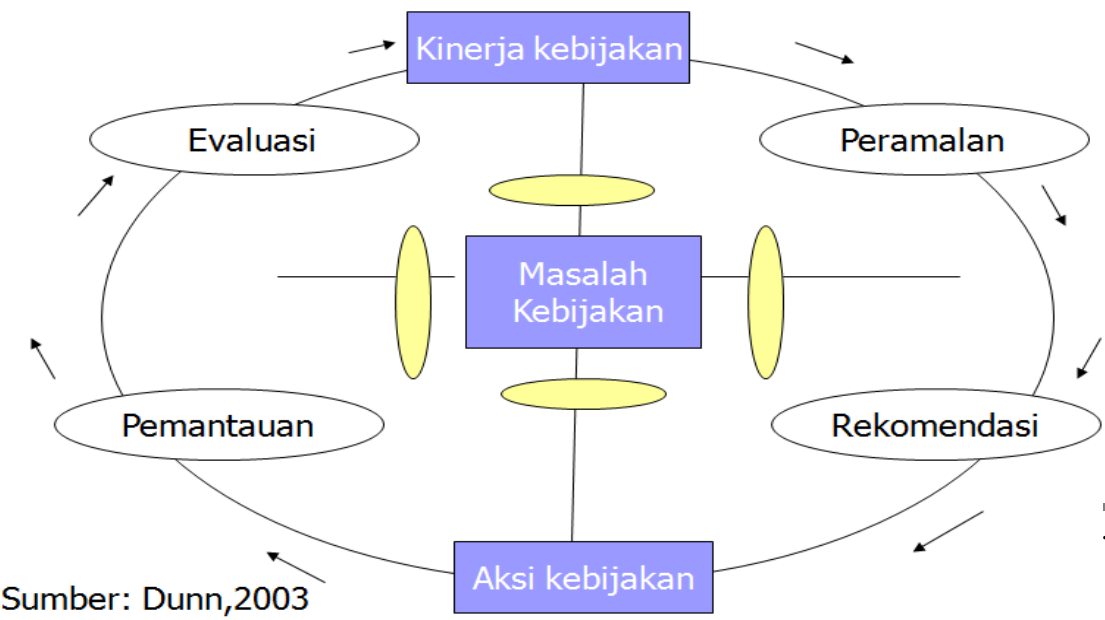




\section{Evaluation of Policy Types}

James Anderson (1975) divides the evaluation of policy into three types:

a. Policy evaluations are understood as functional activities. It concerns the interests and ideology of the policy.

b. Evaluations that focus on the workings of specific policies or programs.

c. Systematic Evaluation of policy. Objectively view the policy programs undertaken to measure their impact on the community and see to what extent these stated objectives are achieved. Answering the impact contribution in answering the needs of the community.

Performance Evaluation policy is undertaken to assess the outcomes achieved by a policy after it has been implemented. The results achieved can be measured in terms of short-term or output, long-term or outcome.

\section{Evaluation of Policy Steps}

Edward A. Schuman posited 6 steps in the policy evaluation, namely:

a. Identify the program objectives to be evaluated Prior to evaluation, a program must be identified in accordance with its objectives and objectives in order to best contribute.

b. Analysis of the problem

Understand carefully the problems that exist in a policy.

c. Description and Standardization of activities

Activities should be clearly defined purpose and benefits, and have a good standard of activity.

d. Measurement of the degree of change that occurs

Changes in a policy should be measured in order to prevent harmful effects. 
e. Determine whether the observed changes are the result of the activity or because of other causes.

The need to identify any changes that occur in a policy, to be immediately known the exact cause and immediately resolved.

f. Some indicators to determine the existence of an impact.

Impacts that occur in the assessment of the policy are determined by some characteristics or measures that have been determined.

(cited in www.academia.Edu/makalah.ian.evaluasi.kebijakan.publik).

\section{Evaluation of Policy Indicator}

There are several indicators of policy evaluation according to some experts. (Dunn 2003: 610) describes the criteria of policy evaluation covering 6 things: effectiveness, efficiency, adequacy, leveling, responsiveness and accuracy. For the next, (Agustino, 2006: 188) Performance policies assessed in the policy evaluation include:

a. How far the needs, values and opportunities have been achieved through policy / program actions.

b. he actions taken by Implementing Agencies are truly effective, responsive, accountable, and fair.

c. effects and impacts of the policy itself.

Based on the reality of the problem of state property management in Sebelas Maret University of Surakarta researchers take the theory put forward by Weiss in (Widodo, 2011: 114) "The purpose of evaluation research is to measure the effects of a program against the goals it set out to accomplish as a means of contributing to subsequent decisions making about the program and improving future programming”.

The purpose of evaluation research is to measure the effects of a program against the goals it set out to accomplish as a means of contributing (recommendation) to subsequent decisions making about the program and improving future programming. 
Based on the description, Weiss's public policy evaluation contains several important elements:

a. To measure the effects based on the research methodology used.

b. Those Effects Emphasize on an outcomes of Efficiency, honesty, morals attached to rules or standards.

c. Comparation between the effects and goals emphasizes on the use of clear criteria In assessing how a policy has been properly implemented

d. Giving contribution to make future decision-making and future policy improvements as the social purpose of the evaluation.

\section{Management of State property}

Management of state property regulated in Law Number 1 of 2004 on the Treasury as stated in the regulation of its implementation as stipulated in Government Regulation Number 6 of 2006 on the Management of State property / region and specially regulated in the Minister of Home Affairs Regulation Number 17 of 2007 on Technical Guidelines Management of Regional Property as well as in the technical level of the use of electronic systems with the application of Management Information System and Accounting of state property (SIMAK BMN) implemented based on Regulation of the Minister of Finance Number 171 / PMK.05 / 2007 on Accounting System and Financial Reporting of Central Government. The management cycle of State property management is shown in the following figure.

Figure 2: Management cycle of State property Management (Source : Permenkeu 171/PMK.05/2007)

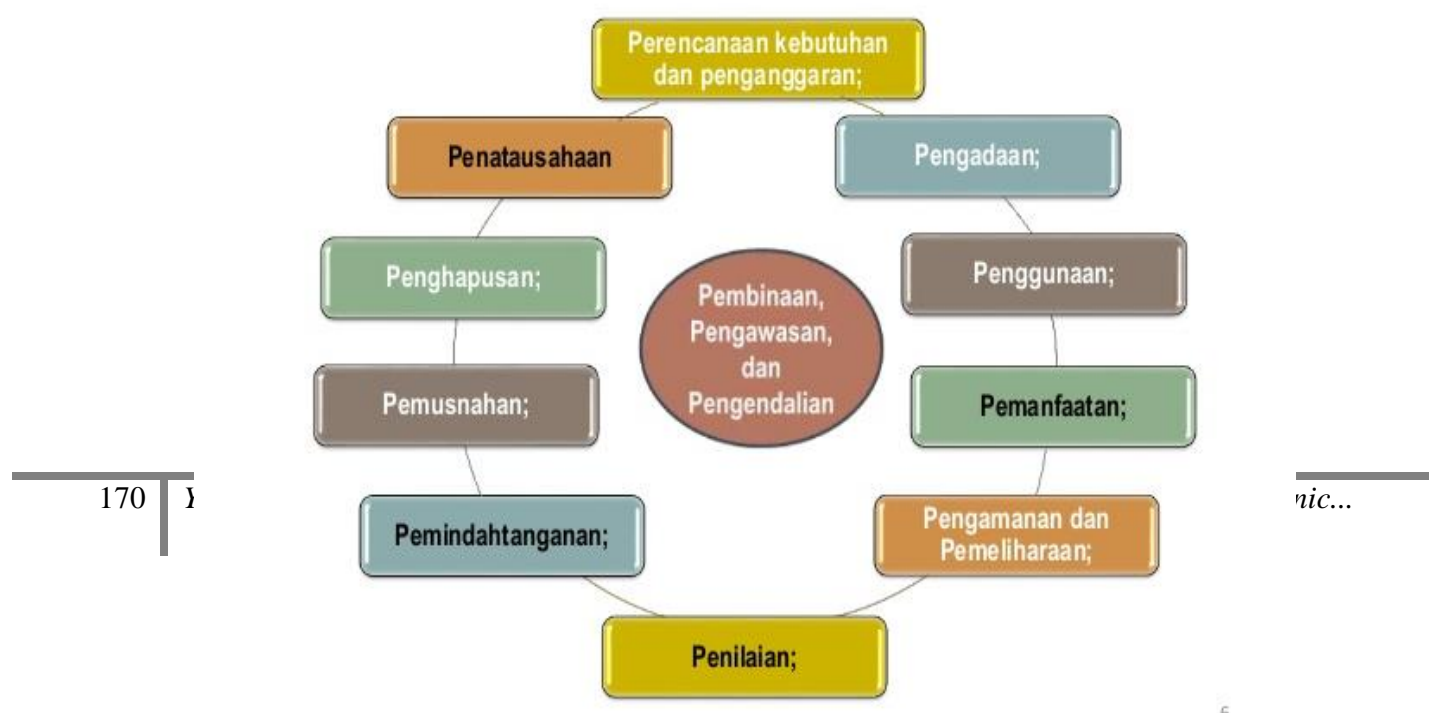




\section{Planning needs and budgeting}

Planning needs and budgeting is the activity of formulating details of the needs of the state property to connect the procurement of properties that have been past with the current state as a base in performing the action to come. Planning needs and budgeting based on property standards, need standards and price standards.

Namely the activity of formulating the details of the state property requirement to connect the past procurement of properties with the current state as the basis for taking action to come. Planning needs and budgeting based on good standards, need standards and price standards

The scope of planning $\mathrm{T}$ Hani that in the planning there are several steps, namely: 1) Setting goals or a set of goals, 2) Formulating the current state, 3) Identify all the conveniences and obstacles, 4) Develop a plan or a series of activities to achieve the goal. Good planning will affect the process of good execution also with the achievement of a goal that has been planned previously (T.Hani Handoko, 1984: 74).

There is a significant difference between requirements planning and budgeting before the enactment of electronic applications with the use of electronic applications (application of Integrated Performance Planning and Evaluation System / SIREN), which appears in the following table:

\begin{tabular}{|l|l|l|}
\hline No & $\begin{array}{l}\text { Manual } \\
\text { Planning }\end{array}$ & Planning with SIREN Application \\
\hline 1 & $\begin{array}{l}\text { Input data } \\
\text { planning and } \\
\text { budgeting } \\
\text { offline with } \\
\text { MS Word or } \\
\text { MS Excel }\end{array}$ & \\
\hline
\end{tabular}




\begin{tabular}{|c|c|c|}
\hline & application & \\
\hline 2. & $\begin{array}{l}\text { Coordination } \\
\text { and } \\
\text { monitoring } \\
\text { is more } \\
\text { difficult } \\
\text { because it is } \\
\text { still manual } \\
\text { by looking at } \\
\text { the print out } \\
\text { planning } \\
\text { documents }\end{array}$ & $\begin{array}{l}\text { Coordination and monitoring at various } \\
\text { levels is easier because online can be } \\
\text { coordinated and monitored remotely } \\
\text { from the virtual world. }\end{array}$ \\
\hline 3 & $\begin{array}{l}\text { The } \\
\text { document } \\
\text { printout is } \\
\text { not sparing } \\
\text { and does not } \\
\text { support go } \\
\text { green }\end{array}$ & $\begin{array}{l}\text { Paperless and strongly support the } \\
\text { development of go green }\end{array}$ \\
\hline 4 & $\begin{array}{l}\text { Reporting } \\
\text { activities are } \\
\text { difficult and } \\
\text { long because } \\
\text { the } \\
\text { document in } \\
\text { the form of } \\
\text { hard copy }\end{array}$ & $\begin{array}{l}\text { Reporting activities is very easy and } \\
\text { fast because it is online }\end{array}$ \\
\hline
\end{tabular}




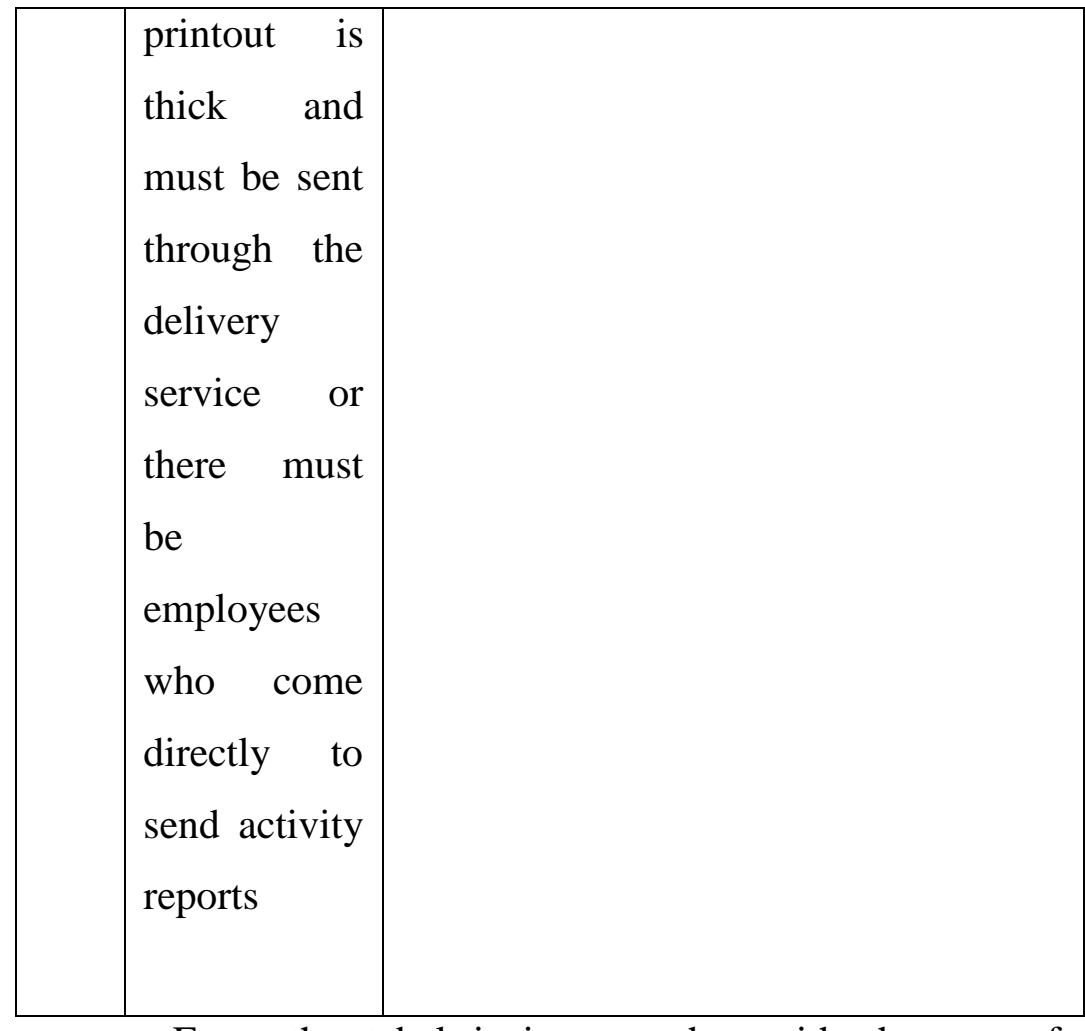

From the tabel it is seen that with the use of SIREN application is very easy in the planning needs and budgeting, but there are still obstacles in the use of such application, such as :

a. The time required for the process of input data planning activities into the SIREN application is less so that it is impressed hastily which resulted in the risk of errors in entering activity data, the selection of activity output and activity budget item is quite high.

b. University policy related to selection of Output activities, Activities, Sub Activity and Activity budget item is often change from year to year so that the planning section takes time to make adjustments.

c. Required human resources (HR) that has the ability and skills in the field of computers and information technology.

The problems that arise in the application of SIREN application in the planning needs and budgeting requires serious attention from stakeholders in the University of Sebelas Maret 
because planning is the key of the next stage of activities in the management of state property implemented in the Sebelas Maret University of Surakarta.

\section{Procurement}

Based on Presidential Regulation Number 54 of 2010 on Guidelines for Procurement of Property / Services for Government Agencies, State-owned property procurement activities carried out based on the principles of efficiency, effectiveness, transparency and an open, competitive, fair / non-discriminatory and accountable.

According to Article 4 of Presidential Regulation Number 54 of 2010, there are four components that become the core of Procurement of Property / Services Government (PBJP) namely: 1) procurement of goods, 2) procurement of construction services, 3) procurement of consultancy services and 4) other procurement services. From these four components it can be seen that all business sectors can be included in the Government Property / Services Procurement component.

The Government has adopted a policy of procurement of properties / services with e-procurement technology designed to facilitate the management of all goods procurement activities via the Internet, covering all aspects of procurement functions supported by various forms of electronic communication (Palmer, 2003 Vol 44 ). E-procurement organized by LPSE (Electronic Procurement Service) is a work unit established throughout the Ministry / Institution / Regional Government Work Unit / Other Institution (K / L / D / I) to organize service system procurement of goods/services electronically (SPSE) as well as facilitate a ULP/Procurement Officials in carrying out the procurement of goods/services electronically is believed to be able to provide benefits and serve as an effective, efficient media, open and competitive, transparent, fair / nondiscriminatory and accountable. The stages, types, procedures and processes concerning procurement of goods / services must adjust the provisions stipulated in the presidential regulation. 
Based on research, there is a significant difference between the goods / services Implementation Manual with Electronic auctions are shown in the following table:

\begin{tabular}{|c|c|}
\hline Man & Electronic \\
\hline $\begin{array}{l}\text { A series of face-to-face meetings } \\
\text { between the committee and } \\
\text { partners (registration, aanwijzing, } \\
\text { acceptance and opening of } \\
\text { bidding documents, verification } \\
\text { of qualifications) }\end{array}$ & $\begin{array}{l}\text { There is a face-to-face meeting } \\
\text { between the committee and the } \\
\text { partners but limited to the } \\
\text { qualification of the winning } \\
\text { candidate }\end{array}$ \\
\hline hardcopy & $\begin{array}{l}\text { Almost all the documents in } \\
\text { digital form }\end{array}$ \\
\hline $\begin{array}{l}\text { The committee work stationary } \\
\text { during the procurement process }\end{array}$ & $\begin{array}{l}\text { The committee can work } \\
\text { anywhere unlimited space and } \\
\text { time as long as it gets access to } \\
\text { communication over the internet }\end{array}$ \\
\hline $\begin{array}{l}\text { Costs required in the } \\
\text { procurement process (eg } \\
\text { document copying, aanwijzing } \\
\text { feeding, bidding and opening of } \\
\text { bids) }\end{array}$ & $\begin{array}{l}\text { Minimize the cost of the } \\
\text { procurement process }\end{array}$ \\
\hline $\begin{array}{l}\text { The opportunity to get a job } \\
\text { through the procurement process } \\
\text { with considerable effort and high } \\
\text { cost because it must be present } \\
\text { physically }\end{array}$ & $\begin{array}{l}\text { The opportunity to get a job } \\
\text { through the procurement process } \\
\text { with effort is quite easy and the } \\
\text { cost is quite low because of } \\
\text { communication through } \\
\text { cyberspace. }\end{array}$ \\
\hline
\end{tabular}

Based on the table it can be seen that the level of efficiency and effectiveness is very noticeable difference. In the electronic auction process 
becomes more efficient as time face to face implemented only during the process of qualifying the potential winner. The effectiveness of electronic bidding is also higher because the committee can work anywhere without any time and space limit, while the manual committee only works during the procurement process only.

Electronic systems also saves the cost of the procurement process followed by a vendor because the vendor no longer need to pay for duplicate documents. Vendors also no longer need to spend the food cost to entertain the auctioneer.

Furthermore, in terms of administration, the comparison between the procurement process manually with electronic procurement process appears in the table as follows:

\begin{tabular}{|l|l|l|l|}
\hline No & Description & Manual & Electronic \\
\hline 1 & $\begin{array}{l}\text { Administration } \\
\text { process }\end{array}$ & Difficult & Easy \\
\hline 2 & Vendor registration & $\begin{array}{l}\text { Over and over } \\
\text { again }\end{array}$ & Just once \\
\hline 3 & Document submit & Come straight & $\begin{array}{l}\text { Through } \\
\text { internet }\end{array}$ \\
\hline 4 & $\begin{array}{l}\text { Frequency face to } \\
\text { face }\end{array}$ & Often & $\begin{array}{l}\text { Almost nothing } \\
\text { (faceless) }\end{array}$ \\
\hline 5 & Confidentiality of & Not guaranteed & Guaranteed \\
\hline 6 & Transparency & Low & High \\
\hline 7 & Competition & Relatively closed & Open \\
\hline 8 & $\begin{array}{l}\text { Opportunities for } \\
\text { KKN }\end{array}$ & Open & Closed \\
\hline 9 & Procurement & Insomnia & \\
\hline
\end{tabular}


The table illustrates that the application of procurement policies to facilitate e-procurement system administration process, in terms of efficiency of electronic systems is more efficient than the manual process because of the document can be sent via the Internet, the electronic system is more transparent than the manual because it can be accessed by anyone, in terms of corruption, collusion, and nepotism $(\mathrm{KKN})$ in electronic systems is also smaller / almost can not practice KKN than manual system.

Implementation of the policy of using e-procurement in the process of procurement of properties / services does provide convenience and profit, but in the implementation also still found some challenges and obstacles such as:

a. The challenge of implementing e-procurement in the government sector can be categorized into system specification and implementation management. (Aman, Aini and Hasmiah, 2011) challenges in specific system specifications are not only related to software integration and data management but also administrative laws and procedures as well as IT infrastructure, while the challenges in implementation management are related to outsourcing contracts and IT capabilities.

b. The implementation of e-procurement among multinational companies will impact on suppliers, especially in SME sectors that often rely on the support and presence of multinational companies located in their region. The digital divide is an important contextual factor for the UN in its consideration of e-procurement (Walker and Harland, 2008).

c. One of the problems in the e-procurement process, namely about the quality of auction goods. A procurement client should consider some issues when picking up a public purchase. (Asa Ronnback, 2012)

d. Other obstacles as stated by Jasin (2007) include: providers of goods / services (vendor) many who do not understand the application of e-procurement, the Procurement Committee majority 
is still struggling to use and understand the application of eprocurement, level of negligence is very high in the use of Passwords and other privacy keys by the user, both the Goods / Services Provider, the Implementation Officer and the Procurement Committee, the auction schedule of the auction may not be fully followed by the Procurement Committee, as appropriate, the availability of internet connection facilities and other supporting facilities (such as scanners, adobe installers, etc.) Limited to the Procurement Committee, Limited bandwidth leads to frequent process failures in e-procurement applications, some worry that their additional earnings when running procurement management activities (starting from procurement, execution and control) will be reduced.

e. Other problems in the implementation of e-procurement is the $\mathrm{CCO}$ (Contract Change Order) is the implementation of procurement contracts of goods / services in this regard are sometimes physical work often have additional work / less able to work due to change technical specifications in accordance with the needs of the field.

Challenges and obstacles in the implementation of a new system is inevitable, therefore it needs support from various parties in finding innovation and new ideas to provide solutions to these emerging problems.

\section{Asset Management / State Property}

Furthermore, in the cycle of management of state property, after the planning and budgeting stage and procurement with e-procurement system, after the asset produced in the form of goods / services from the procurement process the next stage is the asset management / BMN starting from the cycle of use, utilization, security and maintenance, appraisal, diversion, destruction, removal and administration of state assets / property, the Government has issued the 
Minister of Finance RI Number 171 / PMK.05 / 2007 on Central Government Accounting and Reporting System.

At that stage used an electronic application system that is Accounting Management Information System of State Property (SIMAK BMN). Muhamad Nur Afandi and Astri Sulastri in Journal "The Role of Management Accounting Information System of State Property in Supporting Accountability of State Property Management (Case Study at Research Center of Geotechnology LIPI Bandung) Journal of Administration Science Volume IX Number 3 December 2012 "The Institution Accounting System (SAI) has 2 (two) sub system namely Financial Accounting System (SAK) and Management Information System and Accounting of State Property (SIMAK BMN). SAK are used to process budget transactions and their realizations resulting in a Budget Realization Report. SIMAK BMN processes acquisition transactions, changes and deletions of BMN to support SAK in order to produce a Balance Sheet Report”.

Institutional Accounting System (SAI) is organized with the aim to produce the necessary information as a tool of accountability for the implementation of the State Budget and managerial report. SIMAK BMN produces information as the basis for preparing the balance of state ministries / agencies and information for planning needs and budgeting, procurement, use, utilization, security and maintenance, assessment, deletion, diversion, coaching, supervision and control.

Various menu of transactions available in SIMAK BMN application has been prepared as a medium in order to accommodate the stages in the asset management / BMN cycles include:

a. Use

That is the activity carried out by the user of the goods in the main duties and functions of the relevant institution. The goods manager is an authorized official and is responsible for establishing policies and guidelines as well as managing State property, while the goods user is the official holding the authority of the use of State property.

b. Utilization 
It is the utilization of State property that is not used in accordance with the main duties and functions of ministries / institutions in the form of rent, borrow, use and wake-up in order to hand over by not changing ownership status. The form of utilization is described as follows:

a) Rent

Rent is the utilization of property of the state by the other party within a certain period and receive cash rewards.

b) Borrowing Use

Borrowing Use is the delivery of goods between the central government and local government and between local governments within a certain time without receiving the benefits and after the period ends up handed back to the goods manager.

c) Cooperation of Utilization

Cooperation of utilization is the utilization of State property by other party within certain period in order to increase non tax revenue and other financing source.

d) Build Up to Deliver

It is the use of State / local property in the form of land by other parties by establishing the building and / or facilities and facilities, then utilized by other parties within the agreed timeframe, for subsequent relinquishment of land along with the building and / or facilities and facilities After the expiry of the term.

c. Security and Maintenance

The provider of the users of goods and / or the power of goods users shall be obliged to safeguard and maintain the goods belonging to the State / region in their control. Such safeguards include administrative safeguards, physical security and legal safeguards. While Maintenance is a series of activities to maintain the condition and improve all the property of the State / region in order to always be in good condition and ready for use in a useful and effective manner. For the maintenance of property of the State / region must be guided by List of Goods Maintenance Needs (DKPB) . 
d. Assessment

Is a selective process of research activities based on objective and relevant data / facts by using certain methods / techniques to obtain the value of the property of the State / region.

e. Removal

It is the act of removing State / Territory properties from the list of goods by issuing a decree from the competent authority to waive the user and / or the power of the goods user and / or the goods manager from the administrative and physical responsibility of the goods under his control.

f. Diversion

It is the transfer of ownership of State / local property as a follow-up to the removal by way of sale, exchanged, granted or included as government capital. These forms of alienation include:

1) Sales

It is the transfer of ownership of State / Region property to another party by receiving reimbursement in the form of money.

2) Swap

It is the transfer of ownership of State / local property carried out between the central government and local government, or between the central government / local government and other parties, by receiving replacement in the form of goods, at least with a balanced value.

3) Grants

The transfer of ownership of the goods from the central government to local governments, from local governments to the central government, inter-government, or from central / local government to other parties, without obtain reimbursement.

4) Equity Participation of central / regional government It is the transfer of ownership of State / local property and / or originally an asset which is not separated into wealth separated to be calculated as capital / shares of State or region at state owned 
enterprise, regional owned enterprise, or other legal entity owned by State.

g. Administration

Is a series of activities that include bookkeeping, inventory and reporting of State / local property in accordance with applicable provisions.

h. Guidance, Supervision and Control

The Minister of Finance shall establish technical policy and conduct management of state / regional goods. Authorization The properties and properties users shall monitor and control the use, utilization, diversion, administration, maintenance and security of State property / territory under their control.

From the various menu transactions that exist in the application SIMAK BMN produce output in the form of documents / reports as follows:

a. List of Room Goods (DBR)

Is the amount of properties that exist in a room. The data is also not allowed to move or take the goods without the knowledge of SIMAK BMN Operator

b. Properties Inventory Card (KIB) land

Is Inventory Data in the form of Land as Assets of Procurement

c. Properties Inventory card (KIB) Building

Inventory of data is managed and maintained in the form of buildings and building maintenance order in any monitoring can be identified easily

d. Properties Inventory Card (KIB) Motorized Transport Equipment

It is inventory data related to office operations, and is not allowed to be private.

e. Properties Inventory Card (KIB) Armament equipment

Is Inventory Data in the form of weaponry used for something and its use must be through permission.

f. List of Other Properties (DBL)

Is inventory data in the form of all goods other than equipment and machinery 
g. Report of User Power of Attorney (LBKP)

Is a report generated from asset management that can be used as a State Financial Balance Report

\section{h. Goods Condition Report (LKB)}

Is all conditions of the State Property in the inventory of the condition of the goods whether good, heavily damaged, minor damage that will be proposed filed the removal

(Cited via SIMAK BMN Application version 2016)

Judging from the use of the SIMAK BMN application in the management of state assets / property can be obtained several advantages compared to the management of assets manually shown in the following table:

\begin{tabular}{|l|l|l|}
\hline No. & $\begin{array}{l}\text { Manage asset management } \\
\text { Asset management with SIMAK BMN } \\
\text { Application }\end{array}$ & $\begin{array}{l}\text { Data regarding asset / } \\
\text { property of the state can } \\
\text { only be seen in the book } \\
\text { inventory of goods that can } \\
\text { not show accurate data on } \\
\text { the number, condition and } \\
\text { computerized so that the data presented } \\
\text { can show accurate data on the number, } \\
\text { condition and existence of assets }\end{array}$ \\
\hline 2 & $\begin{array}{l}\text { Administration of assets is } \\
\text { manual (offline) so it is } \\
\text { quite difficult to be accessed } \\
\text { by interested parties }\end{array}$ & $\begin{array}{l}\text { Administration of assets (Bookkeeping, } \\
\text { Inventory and Reporting) electronic } \\
\text { assets (online) more transparency, more } \\
\text { easily accessible through the website or } \\
\text { Software (Computers, HP and so on) by } \\
\text { orderly, making it difficult }\end{array}$ \\
\hline 3 & $\begin{array}{l}\text { Administratively } \\
\text { users or parties who manage the State } \\
\text { Property }\end{array}$ \\
\hline
\end{tabular}




\begin{tabular}{|l|l|l|}
\hline & for monitoring & \\
\hline
\end{tabular}

Based on the above table, the application of SIMAK BMN Application in asset management is not limited to only in the form of reports but reports from the output of SIMAK BMN Application must be accurate and reliable and accountable, so that at the time of the Audit can bring up WTP Opinion (Reasonable Without Exception) from the Auditor Team.

\section{CLOSING}

\section{Conclusion}

Based on the results of research in the field and based on theories related to research, Evaluation of Electronic State Property Management Policy At Sebelas Maret University Surakarta based on Weiss concept there are 4 (four) important elements, as follows:

1. To measure the impact (to measure the effects) by relying on the research methodology used.

The implementation of the Electronic State Property Management policy has a positive and positive impact for Sebelas Maret University, because it has developed e-Governance by applying electronic system in every stages of State Property management in planning, procurement and asset management. The management of state property is more orderly, avoiding $\mathrm{KKN}$ practices, it is costeffective, efficient, transparent and more accessible.

2. The impacts emphasize an outcomes of efficiency, honesty, morals attached to rules or standards.

Completion of the system is carried out every year from the beginning of the implementation of the policy management of state property Electronically have a positive impact on the University of March Surakarta efficiency in terms of both cost efficiency and time efficiency. Based on this research, the impact (effects) that emphasize a results (outcomes) are: a) Direct supervision of the community or students in the implementation of the management 
of State Property so as to avoid Corruption, Collusion and Nepotism (KKN), b) Good work from planning, procurement of goods / services and asset management meet the target, c) Minimize the cost of the University of Eleven March, work unit, provider of goods / services, and operator of asset management.

3. Comparison between effects with goals emphasizes the use of clear criteria in assessing how well policies are implemented.

Electronic State Property Management at Sebelas Maret University is implemented based on the rules set by the government and the Rector and in accordance with the expected objectives. Initially all activities related to the management of State Property is done by manual now everything is done electronically so it is very supportive in order to achieve the goal of Sebelas Maret University to World Class University. For the providers of goods / services and the wider community also has a broader criteria in conducting assessments that are transparent, fair / non-discriminatory, responsible, effective and efficient.

4. Contribute to future decision making and future policy improvements as the social purpose of the evaluation.

The implementation of electronic management of state property of Sebelas Maret University Surakarta gives good contribution in government and society as user. The contribution given is good for the internal university as well as for the community that is in the case of the construction of adequate facilities and educational facilities. So for the next decision-making the same as previous years, but there is always renewal both technically and nontechnical.

\section{Suggestions}

The existence of obstacles or problems that arise during the implementation of the management of State Property electronically in Sebelas Maret University Surakarta, can be done as follows: 
1. Conducting university and roadshow socialization to the faculties and work units so that all relevant stakeholders can understand and understand about the management of state property electronically.

2. Providing direction to the users (Lab / Section / Sub Section) to immediately report the need of Procurement to KDP so that the process of preparing the HPS is not too late, so the procurement process can be done immediately.

3. Take firm action against providers of goods / services (vendors) if in the procurement process until the implementation of problematic work or doing the cheating.

4. In order to improve the competence and skill of employees, it is necessary to involve employees in the training / training on the management of state property electronically.

\section{BIBLIOGRAPHY}

Agustino, Leo. 2006. Dasar-Dasar Kebijakan Publik (Basic of the Public Policy). Bandung: CV. Alfabeta.

Anderson, James A. 1975. Public Policy Making: Basic Concept in Political Sciences. New York: Praeger University Series.

Dunn, Willian N. 2003. Pengantar Analisis Kebijakan Publik Edisi Kedua (Introduction to Public Policy Analysis, Second edition), Yogyakarta: Gadjah Mada University Press

Handoko, T.Hani. 1984. Manajemen. Yogyakarta : BPFE 
Jasin, M. 2007. Mencegah Korupsi Melalui E-Procurement (Preventing Corruption by E-Procurement). Jakarta : Komisi Pemberantasan Korupsi.

Nawawi, Hadari.1985. Metode Penelitian Bidang Sosial (Research Methods on The Social Sciences). Yogyakarta : Gajah Mada University Press.

Putra, Fadillah. 2003. Paradigma Kritis dalam Studi Kebijakan Publik (Critical Paradigm in the Study of Public Policy). Yogyakarta : Pustaka Pelajar.

Widodo, Joko. 2011. Analisis Kebijakan Publik: Konsep dan Aplikasi Analisis Proses Kebijakan Publik (Analysis of the Public Policy: Concept and Application of the Analysis of Public Policy Process). Malang : Bayu Media.

Winarno, Budi. 2008. Kebijakan Publik Teori dan Proses. Jakarta : PT Buku Kita.

\section{Journals:}

Aman, Aini and Hasmiah Kasimin. 2011. "E-procurement implementation: a case of Malaysia government, Transforming Government: People, Process and Policy”. International Journal Vol. 5 Iss 4 pp. 330 - 344. Malaysia.

Nur Afandi , Muhamad dan Astri Sulastri.2012. "Peranan Sistem Informasi Manajemen Akuntansi Barang Milik Negara Dalam Menunjang Akuntabilitas Pengelolaan Barang Milik Negara (Studi Kasus Di Pusat Penelitian Geoteknologi Lipi Bandung)".Jurnal Ilmu Administrasi.Vol.IX.no.3. 
R. Palmer. 2003. "Moving Procurement Sistems to The Internet: The adoption and use of e procurement technology models". European Managememnt Journal, Vol.44.Hal 17-25..

Ronnback, Asa. 2012. "Quality in the public procurement process". The TQM Journal, Vol. 24 Iss 5 pp. 447- 460. Sweden.

Walker, Helen and Christine Harland. 2008. "E-procurement in the United Nations: influences, issues and impact. International Journal of Operations \& Production Management”.Vol. 28 Iss 9 pp. 831 857. UK.

\section{Internet :}

https://www.academia.Edu/makalah.ian.evaluasi kebijakan publik. dikutip pada tanggal 24 November 2016. Pukul 19.45 WIB.

\section{Regulations :}

Law Number 25 of 1999 on the Financial Balance Between Central and Local Government

Law Number 1 of 2004 on The State Treasury

Law Number 32 of 2004 on The Local Government

Presidential Decree Number 80 of 2003 on The Procurement of Government Goods and Services

Presidential Decree Number 54 of on The Procurement of Government Goods and Services

Government Regulation Number 6 of 2006 on The Management of State Property

The Ministry of Home Affairs Number 17 of 2007 on The Technical Guidances of Regional Property 
The Ministry of The Financial Affairs Number 171/PMK.05 of 2007 on The Central Government Accounting System (SAPP). 